شيوع زنوتيّ هاى متفاوت(CASQ1 rs2275703(A/C در بيماران مبتلا به T2DM

$$
\begin{aligned}
& \text { رسول نصيرى كالمرزى'، سميه بداقى'، آزاد فتاحى رادّ، فاطمه كشاورزى } \\
& \text { () مركز تحقيقات بيمارى هاى ريه و آلرثى، دانشكاه علوم يزشكى كردستان، سنتدج، إيران } \\
& \text { N) كروه زيست شناسى، ولحد سنندج، دانشكاه آزاد اسلامى، سنتدج، إيران } \\
& \text { ر بيمارستان توحيد، دانشكاه علوم يزشكى كردستان، سنندج، إيران }
\end{aligned}
$$

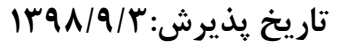

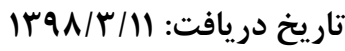

\footnotetext{
קֶيده

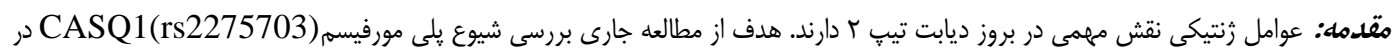

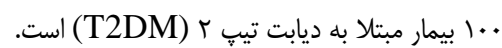

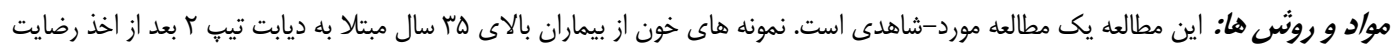

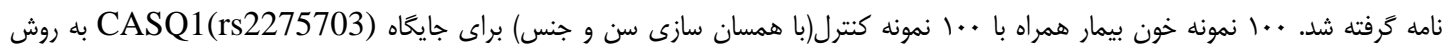
tetra-arms PCR

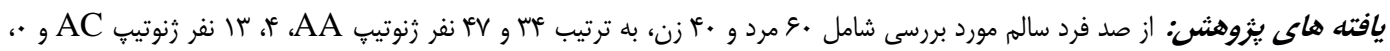

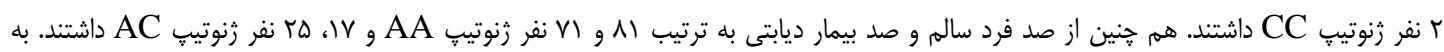

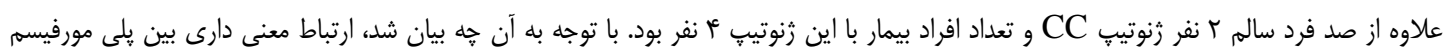

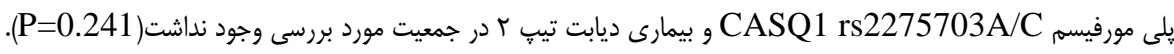
بحث و نتيجه تحيرى: يلى مورفيسه CASQ1 rs2275703A/C ارتباط معنى دارى با ديابت تيب ז در جمعيت مورد مطالعه ندارد.
}

وازه هاى كليدى: يلى مورفيسم زنتيكى، CASQ1 rs2275703A/C، ديابت تيب r

Email:gol.keshavarzi@gmail.com

* نويسنده مسئول: گروه زيست شناسى، واحد سنندج، دانشگاه آزاد اسلامى، سندج، ايران

Copyright $(\odot 2019$ Journal of Ilam University of Medical Science. This is an open-access article distributed under the terms of the Creative Commons Attribution international 4.0 International License (https://creativecommons.org/licenses/by-nc/4.0/) which permits copy and redistribute the material, in any medium or format, provided the original work is properly cited. 
هاى CASQ1 و CASQ2 كدى شــــند و به ترتيب

مقدمه

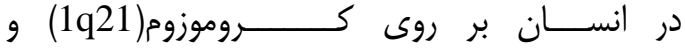

(1p13/3-p11)

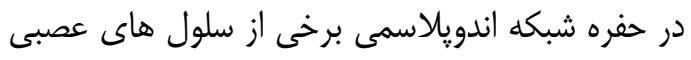
و عضلات صاف هم وجود دارند(9). تزارش شده كار كه فعالانه در يروسه آزادسازى كلسيم نقش دارد به طورى كه كلسيم را در كانال آزادســـازى متمركز

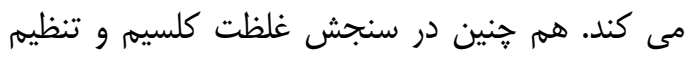

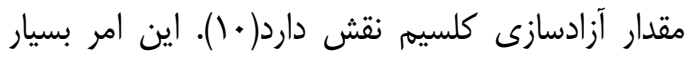
مهمى است زيرا كلسيم|(Ca است كه در بسيارى از مسيرهاى انتقال ييام نظير لقاح،

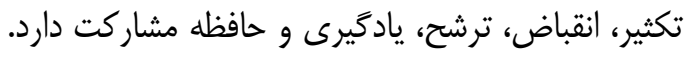
توانايى سيكنال هاى Ca مناسب بستخى دارد. شايان ذكر است كه افكتورهاى

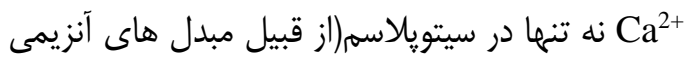
معروف مانند يروتئين كيناز (PKC) C)، يروتئين كيناز

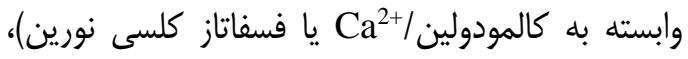
بلكه در اندامـــك هاى محسصور در غشا(هسته، شبكه اندويلاسمى(ER)، كَلثى و ميتوكندرى) قرار دارند( •(1). افكتور PKC با اتصال كلسيم فعال مى شود و سيس

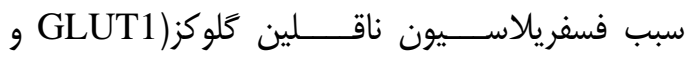

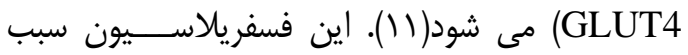

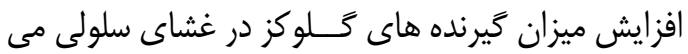

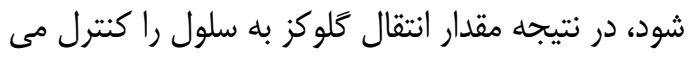
كند. يس افزايش كلسيم سيتويلاسمى كام مهمى است در فعال شدن آبشار درون سلولى كه واسط اثر فورى و طولانى مدت حمل و نقل گلوكز است، دارد(1(1). لذا در

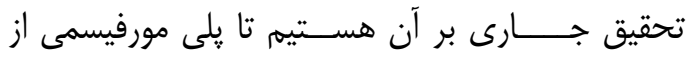
اين زن را كه در مطالعات كذشته شيوع آن در افراد مبتلا

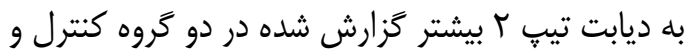
مبتلا به ديابت تيب إ در كردستان بررسى كنيه.

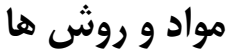

بيماران: تحقيق حاضر يكى مطالعه مورد-شاهدى

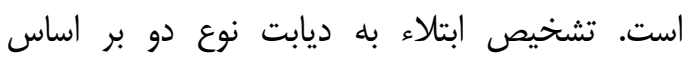
معيارهاى آزمايشخاهى ADA (انجمن ديابت آمريكا)

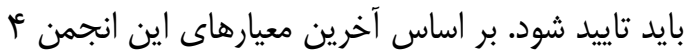
ويزگى براى ابتلا به ديابت مليتوس در بيمار بايد وجود داشته باشد و توسط يزشك متخصص ايتلائ ديايت مليتو در بيدار بايد شود. اين
بيمارى هاى شايع جند عاملى، طبيعت مزمنى داشته

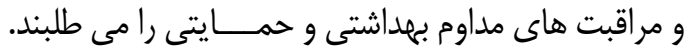

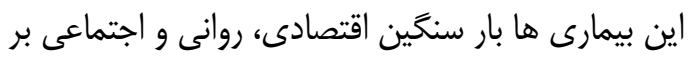

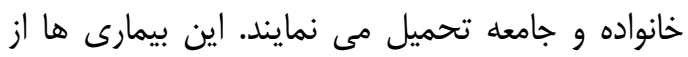

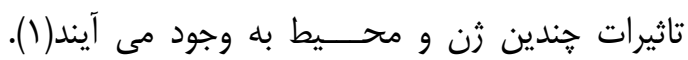
دقت در نقش عوامل زنتيكى و ارثى در كنار عوامل محيطى در ييشخيرى، تشخيص زودرس، درمان بيمارى

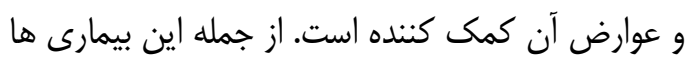

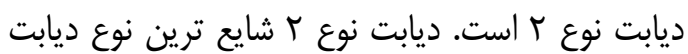

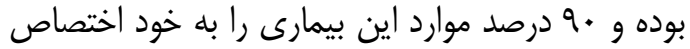
داده است(ץ). شيوع ديابت نوع r ييوسته در حال افزايش

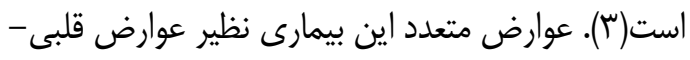

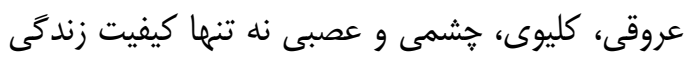

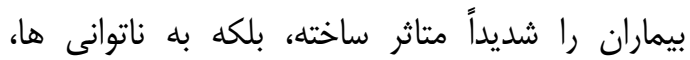
معلوليت هاى زودرس و افزايش مرى و مير بسيارى از

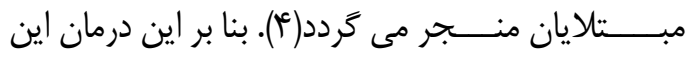

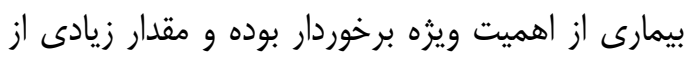
بودجه بهداشتى جوامع را به خود اختصاص مى دهد. عوامل زنتيكى نقش مهمى در بروز ديابت نوع r دارند.

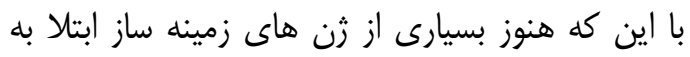

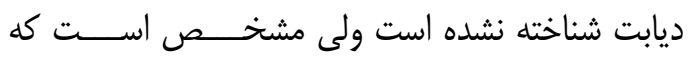

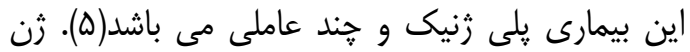

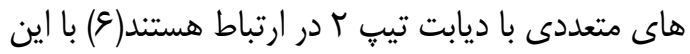

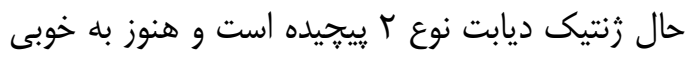

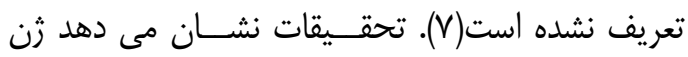
CASQ1 با ديابت تيب ז مرتبط است(^). ثن CASQ1

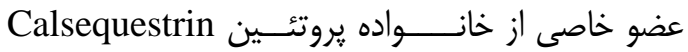
را در عضلات اسكلتى كد مى كند. عملكرد اين بروتئين به عنوان سنسور كلسيم مجارى شبكه سار كويلاسمى در سلول هاى ماهيجٍه اســـكلتى و ماهيجه قلبى است. فراوان ترين يروتئســين ميان يروتئين هاى شبكه

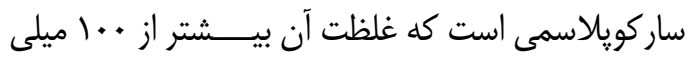

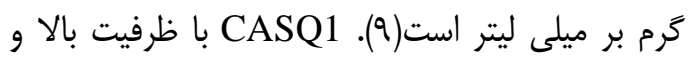

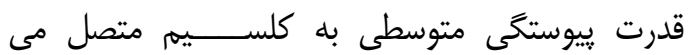
شود(·). دو ايزوفرم عمده CASQ1 وجود دارد

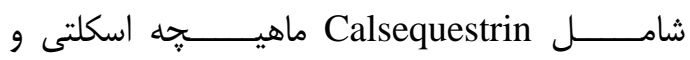

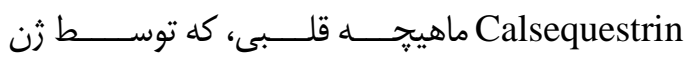


شده و در ويال حاوى EDTA براى انجام PCR در

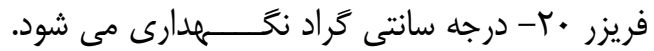
ملاحظات اخلاقي: اصول اخلاقى، يثوهشگران و به به ويزه افراد با كاركردهاى خاص راد راد در سطح جامعه ملزم مى كند كه اصولى رفتار كنند؛ زيرا هر قدر مسئوليت ها مهم تر و جدى تر باشد، تكليف هاى ناشى از رعايت اصول اخلاقى و اخلاقيات بيشتر است. جندين اصل

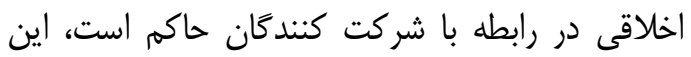
اصول شامل اين موارد مى باشد: رضايت آكاهانه

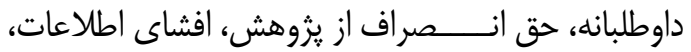

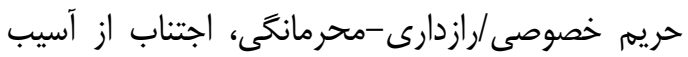

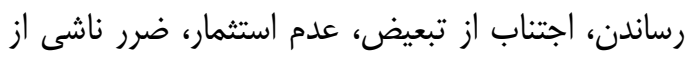
مشار كت در يثروشن. آزمايشات مولكولى مثارك درهن

استخراج DNA از خون با /ستغاده /ز محلول د. DNAfast

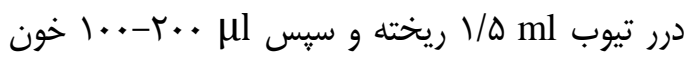
به آن اضافه شد و به مدت يك دقيقه اين مخلوط به

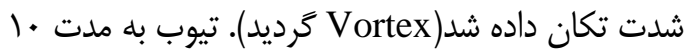

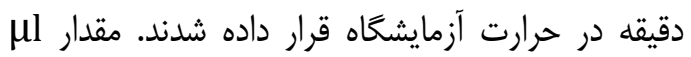

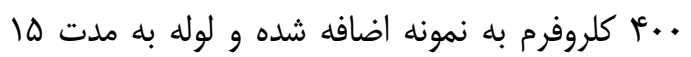

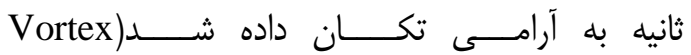

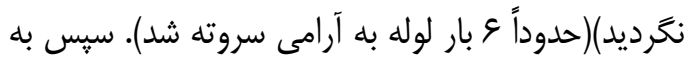

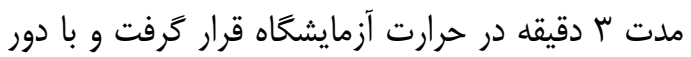

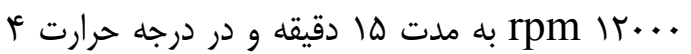

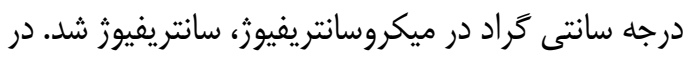
اين مرحله ب فاز مشخص در تيوب ايجاد شد، محلول

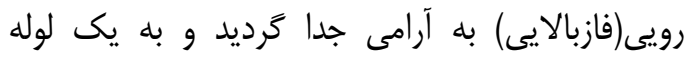

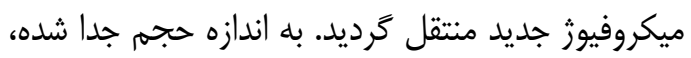

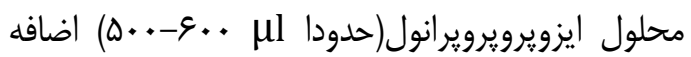
شد و به خوبى Vortex گر ديد. سيس تيوب حاوى نمونه به مدت ها دقيقه بر روى يخ خرد شده قرار داده شد. در

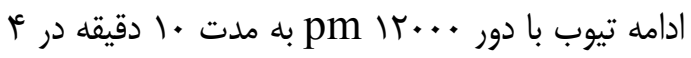
درجه سانتى گراد سانتريفيوز گرديد. به آرامى محلول رويى را خارج و رسوب حاصل در ته لوله باقى ماند.

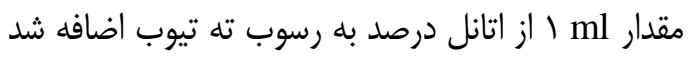

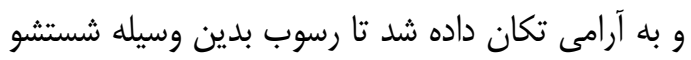

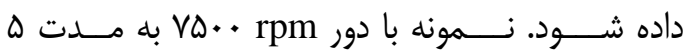

معيارهاى ع كانه عبارتند از: ا. هموكلوبين قندى يا مساوى يا بيشتر از هاع درصد بر اساس

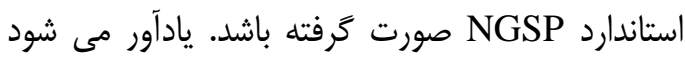

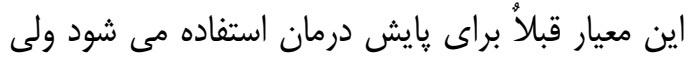
در حال حاضر معيار تشخيصى نيز تلقى مى شود. r.

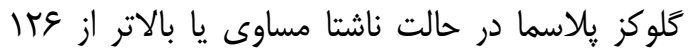
ميليخرم در دسى ليتر باشد. حالت ناشتا يعنى اين كه شخص حداقل براى ^ ساعت هيج كالرى دريافت نكرده باشد. لازم به ذكر است كه در غياب علائم صريح هيير كليسمى يعنى يلى اورى، يلى دييسى و كاهش وزن اين يافته بايد با تكرار تست در روز ديكر تاييد كردد. بّا.

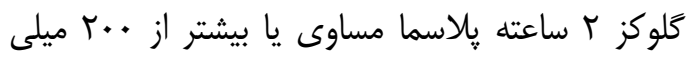

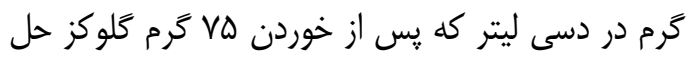
شده در آب در خلال تست تحمل كلوكز استاندارد تعيين شده باشد. fا. خنان خه علائم هيير كليسمى موجود باشد

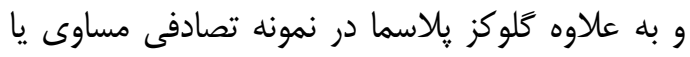
بيشتر از +." ميلى گرم در دسى ليتر باشد. نمونه خون از بيمار ان مبتلا به ديابت نوع ؟ بر اساس معيارهاى بيان شده، هم جنين افراد سالم به همان تعداد گرفته مى شود.

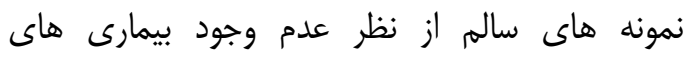

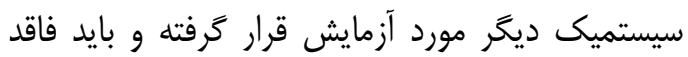
بيمارى سيستميك ديخر باشند. هم جنين بيماران نيز از نظر نداشتن بيمارى سيستميك ديگر بررسى شده و فاقد

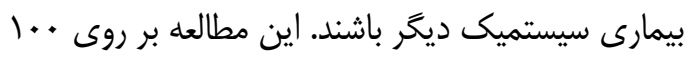

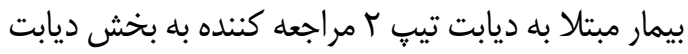
بيمارستان توحيد سنتدج به همراه +..1 فردد سالم بدون

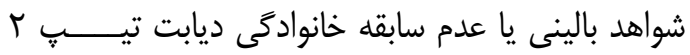

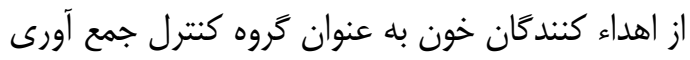

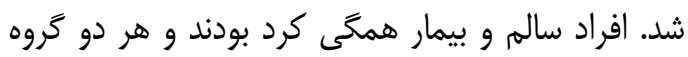
از لحاظ سن و جنس همسان سازى شدند. بعد از انتخاب بيماران و افراد كنترل، در ابتدا اطلاعاتى به صورت كتبى لنقان

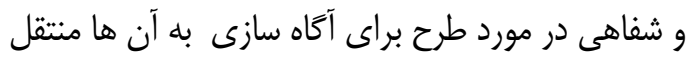
شد. هم جنين موافقت نامه هاى اطلاعاتى از تمام موضوعات مورد مطالعه بر اساس يروتكل تاييد شده

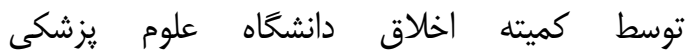
كردستان(D.P.16.35.2510) از داوطلبين به دست آمد. در ادامه دو ميلى ليتر خون از هر فرد(سالم و بيمار) كَرفته 


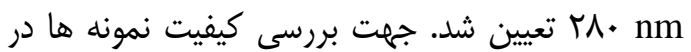
اين يزوهش از زل آكارز نيز استفاده شد. Tetra-ARMs PCR جهار يرايمر براى هر جايگاه مى باشد كه هر أ يرايمر را:

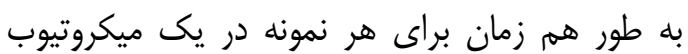

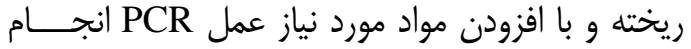

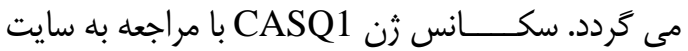

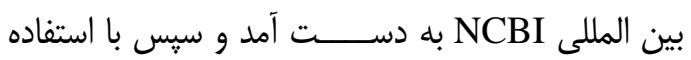

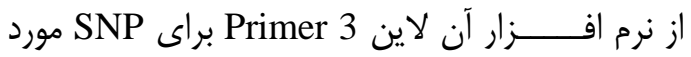

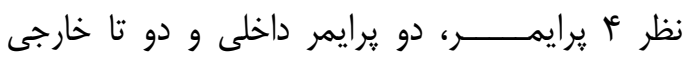
طراحى شد. بعد از طـــــــراحى جهت سنتز به شركت

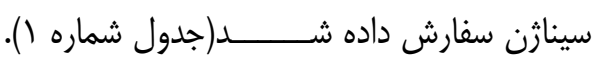

دقيـــــه در ع درجه سانتى گراد سانتريفيوز گرديد. به آرامى مايع رويى خارج گرديد و رسوب DNA در ته تيوب باقى ماند. در ادامه تيوب به مدت · إ دقيقه در

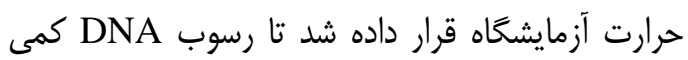

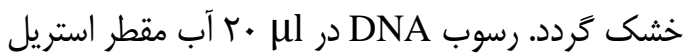
حل شد. براى اطمينان از كيفيت DNA مقدار l نمونه بر روى زل آكاروز V/ • درصد و با استفاده از رنگ آميزى اتيديوم برومايد و اشعه UV ملاحظه كرديد. ارزيابيى كمى و كيفى DNA: يس از استخراج DNA

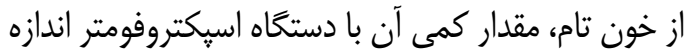
گيرى شد. غلظت DNA و يروتئين هر نمونه بر حسب

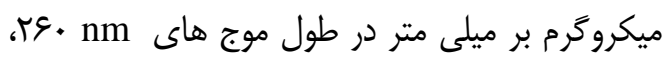

جدول شماره ا. برايمرهاى بلى مورفيسم CASQ1 جهت انجام Tetra-ARMS PCR

\begin{tabular}{cccc}
\hline SNP & system & Primer sequence $\left(5^{\prime}-3^{\prime}\right)$ & Allele \\
\hline \multirow{5}{*}{ rs2275703 } & Forward inner primer & (A); 5'GTACTCTGGGGGTTCCCAGACAAACA3' & A \\
& Reverse outer primer & 5'ACATCACCCAGTGTCTCAGCCTCTACCT3' & \\
& Reverse inner primer & (C); 5'TGAGGGGAAGGTGGAATACTGGAAGG3' & C \\
& Forward outer primer & 5'AGCTGCATCCTCGAAGGCTTTGTAATCT3' & \\
\hline
\end{tabular}

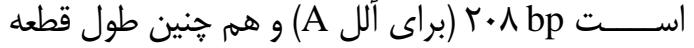
حاصـــــل از يرايمرهاى Forward خارجى و Reverse

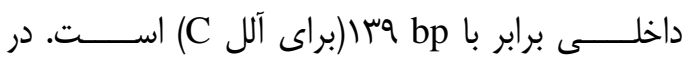

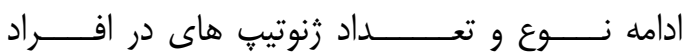
ســـــالم و ديابتى با روش Tetra-ARMS PCR و و

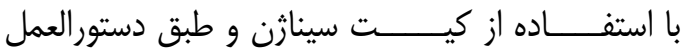
مربوط انجام شد(شكل شماره ().
زوج يرايمرهاى مورد استفاده شامل يك جفت يرايمر خارجى عمومى و يكى جفت هرايمر داخلى اختصاصى آلل براى هر زن بود. اندازه قطعاتى كه به

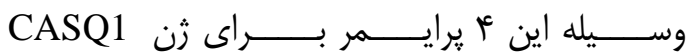
(rs2275703) تكثير مى شد، به شرح ذيل است: قطعه تكثيرى حاصل از يرايمرهاى Forward و Reverse

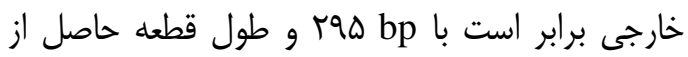
يرايمرهاى Forward داخلى و Reverse خارجى برابر 


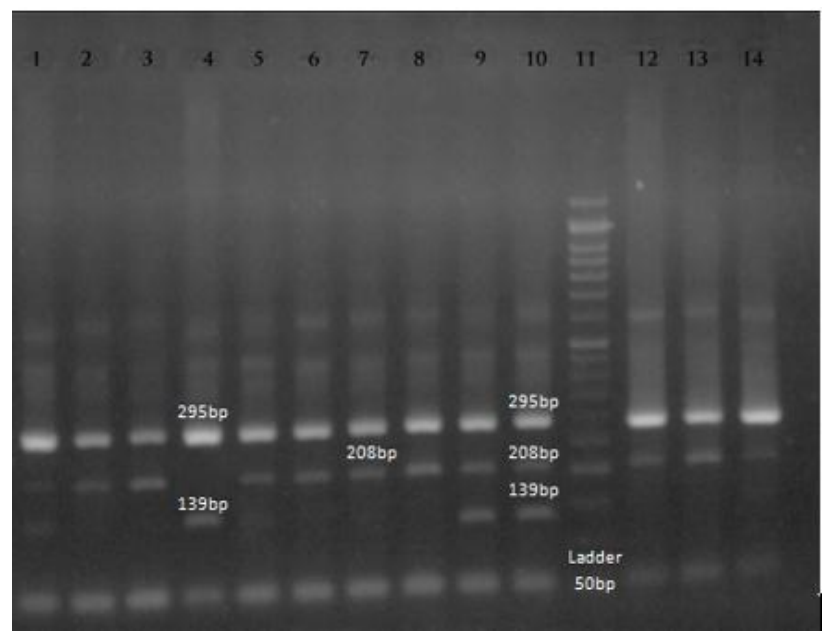

شكل شماره (. تصوير الحوى الكتروفورزى محصولات PCR زن (rs2275703) (Fasq1) زوج برايمرهاى مورد استفاده شامل دو برايمر

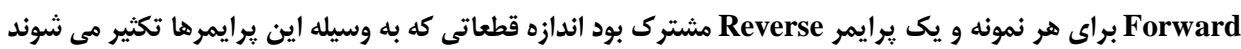

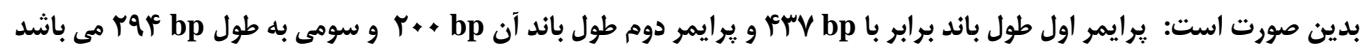

4: Homo C/C (Control: 295 bp, C: 139 bp)

7: Homo A/A (Control: 295 bp, A: 208 bp)

10: hetro A/C (control: 295 bp, A:208 bp, C:139 bp)

11: ladder 50 bp

شركت داشته اند. افراد سالم فاقد هر گونه بيمارى يافته هاى يثزوهش

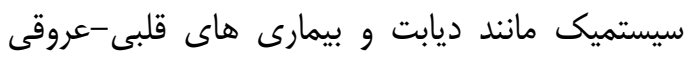

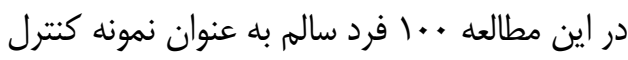
بودند. از صد فرد سالم مورد بررسى •ع نفر مرد و • أنفر

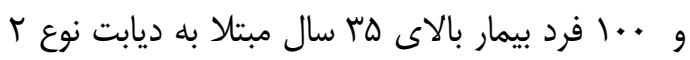
زن بودند، توزيع زنوتيٍ ها در جدول شماره ب آمده است.

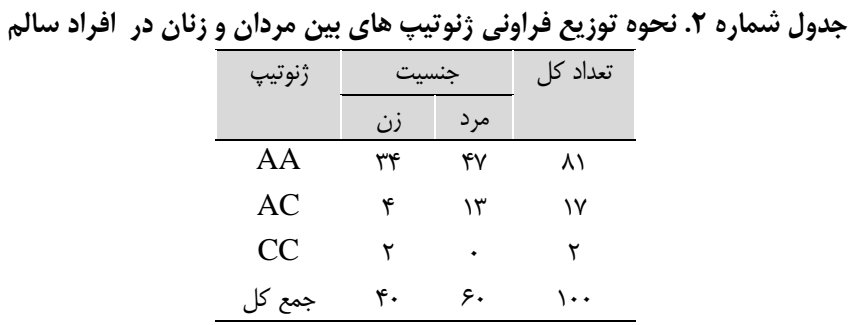

يكسان است يا خير؟ براى بررسى اين فرض، از آزمون

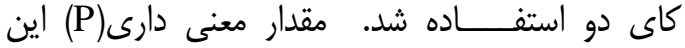

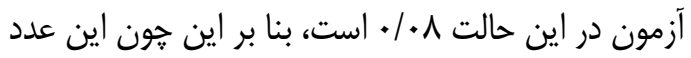

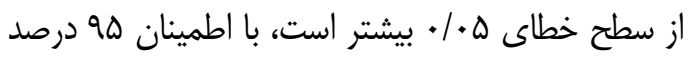

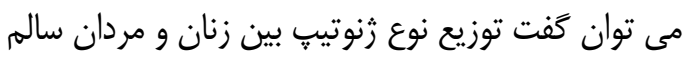

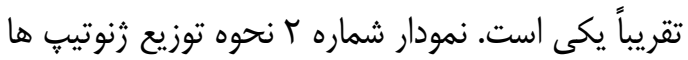
را با توجه به جنسيت واضح تر نشان مى دهد.
همان طور كه جدول نشان مى دهد از • ع نفر خانم

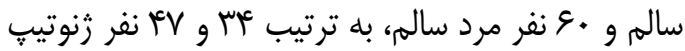

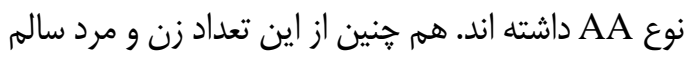

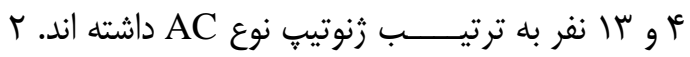
نفر از خانم ها زنوتيب نوع CC داشته و هيج مردى اين

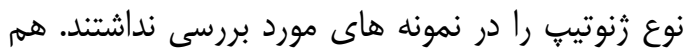

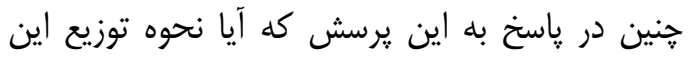

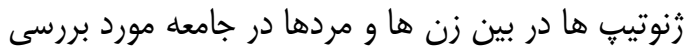




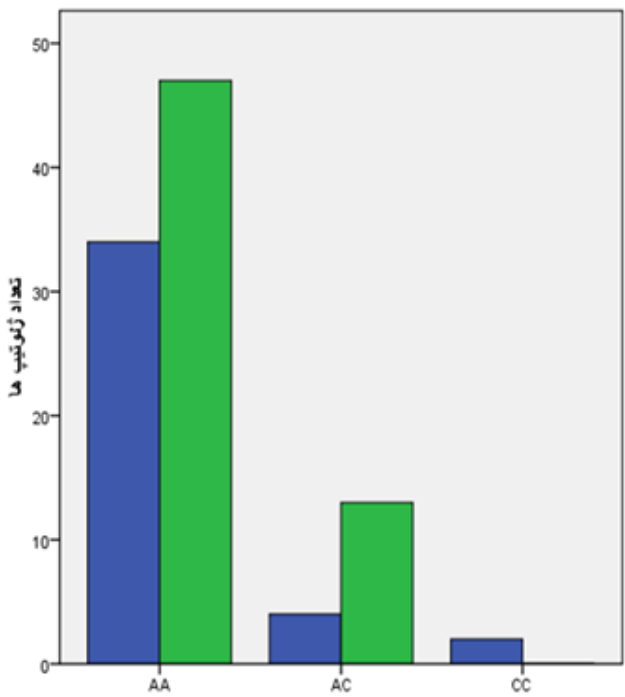

回”

شكل شماره r. شيوع زنوتيب هاى CC, AC, AA در افراد سالم

تعداد افراد با زنوتيب CC دو نفر ساختن فاصله اطمينان

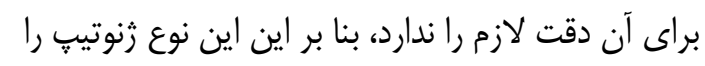

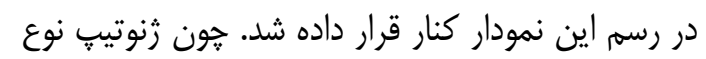

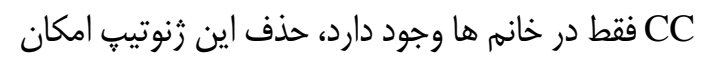

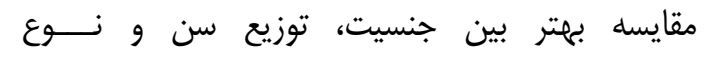

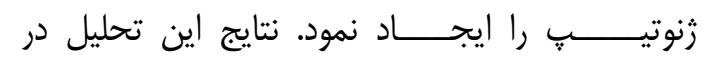
نمــــــــارهاى شماره بَ و ع آمده است.
نمودار شماره r نشان مى دهد با وجود بيشتر بودن

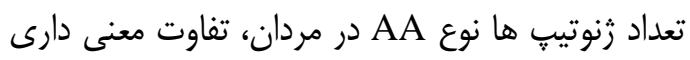

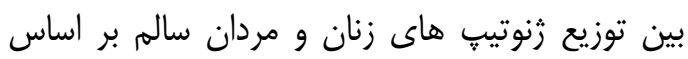

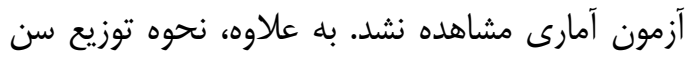

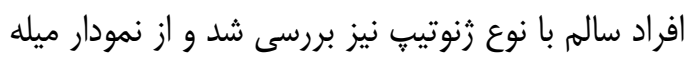

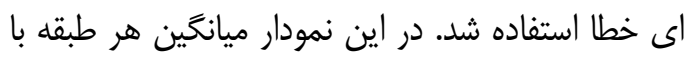
يكى نقطه و با محاسبه واريانس، يكى فاصله اطمينان براى داده هاى آن طبقه رسم شد. جون در افراد سالم ئم

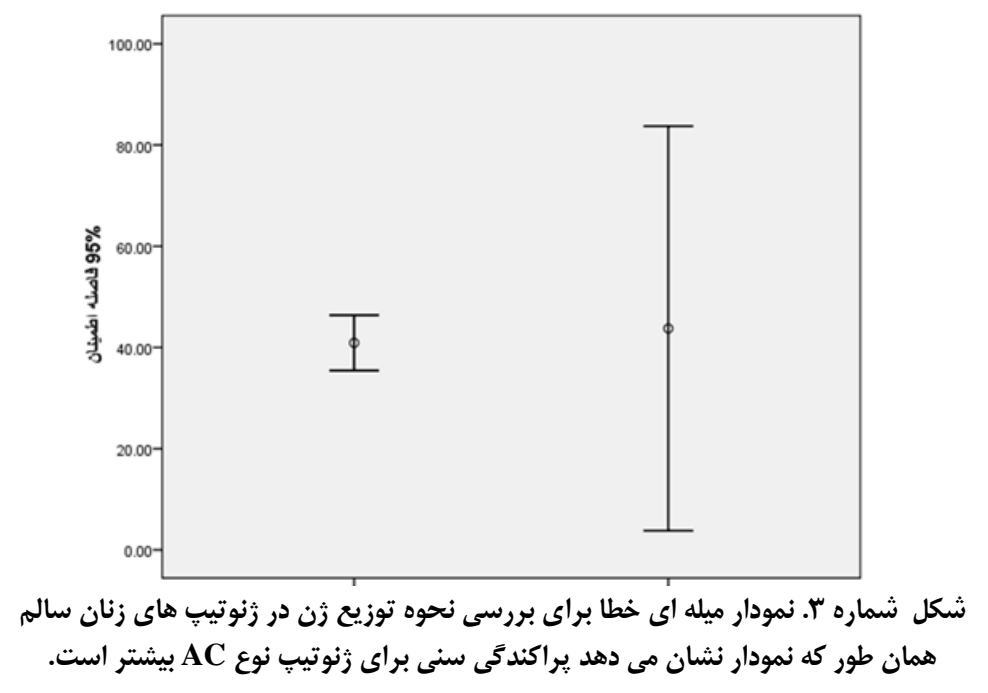




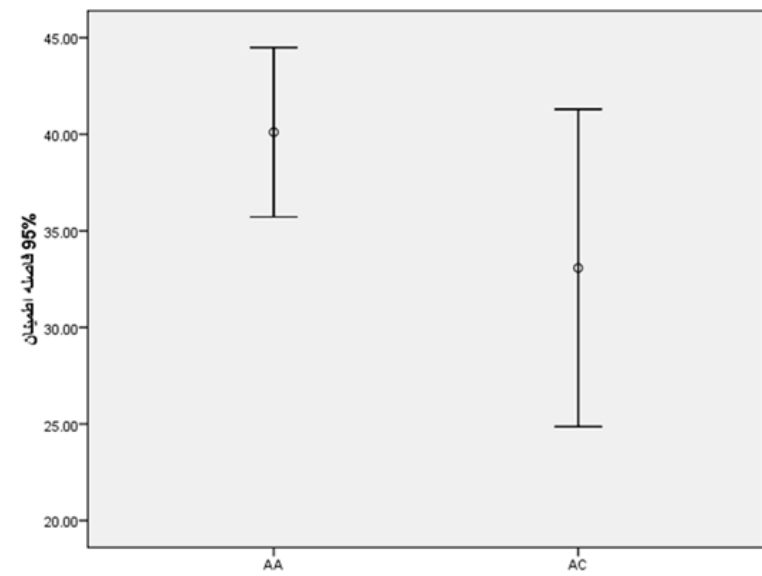

شكل شماره أ. نمودار ميله ای خطا براى بررسى نحوه توزيع سن در زنوتايڤ هاى مردان سالم

مردان سالم از ميانگين سنى زنوتيب نوع AC بيشتر

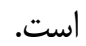

براى بررسى رابطه زن CASQ1 با بيمارى ديابت، نوع زنوتيڤ افراد سالم و بيماران ديابتى را با تشكيل جدول توافقى، به طريق مشابه مورد مقايسه قرار كرفت.
شكل شماره أ نشان مى دهد، ير اكندگى سنى براى

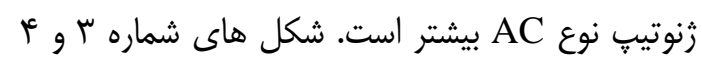

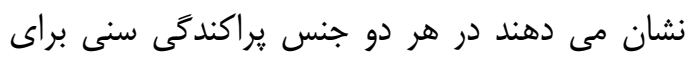
رنوتيٍ نوع AC بيشتر است. با وجــود اين در خانم

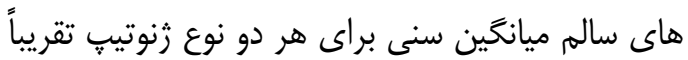

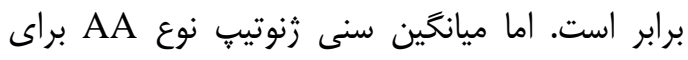

\begin{tabular}{|c|c|c|c|}
\hline \multirow[t]{2}{*}{ نوع رنوتيب } & \multicolumn{2}{|c|}{ وضعيت سلامتى افراد } & \multirow[t]{2}{*}{ تعداد } \\
\hline & سالم & بيماران ديابتى & \\
\hline AA & $\wedge 1$ & n & IQT \\
\hline $\mathrm{AC}$ & IV & ra & et \\
\hline $\mathrm{CC}$ & r & r & 9 \\
\hline جمع كل & $1 \ldots$ & $1 \ldots$ & $r_{*}$ \\
\hline
\end{tabular}

افراد سالم) برابر أب//• است. اين عدد از مقدار خطاى

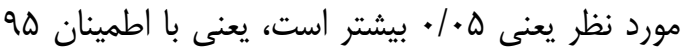
درصد مى توان كَت كه رابطه معنى دارى بين نوع

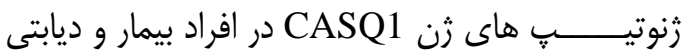
وجود ندارد. شكل شماره ه نمودار ميله اي توزيع نوع

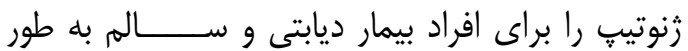

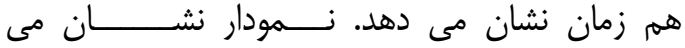

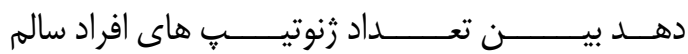
و بيمار تفاوت معنى دارى نيست.
جدول شماره r نشان مى دهد كه از صد فرد سالم و صد نفر بيمار ديابتى به ترتيب ایم و ال نفر داراى زنوي״ AA هستند. هم جنين از صد فرد سالم و صد نفر

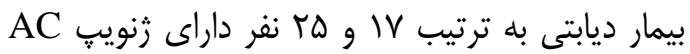

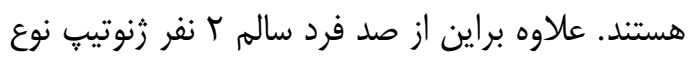
CC و تعداد اين نوع زنوتيّ براى افراد بيمار ك است.

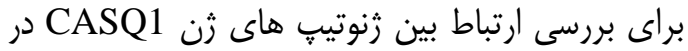

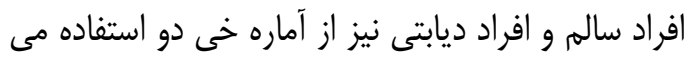

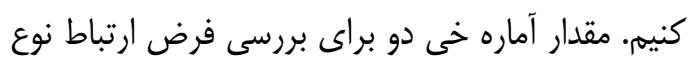
زنوتيٍّ ها با وضعيت سلامتى افراد (بيماران ديابتى يا ديا 


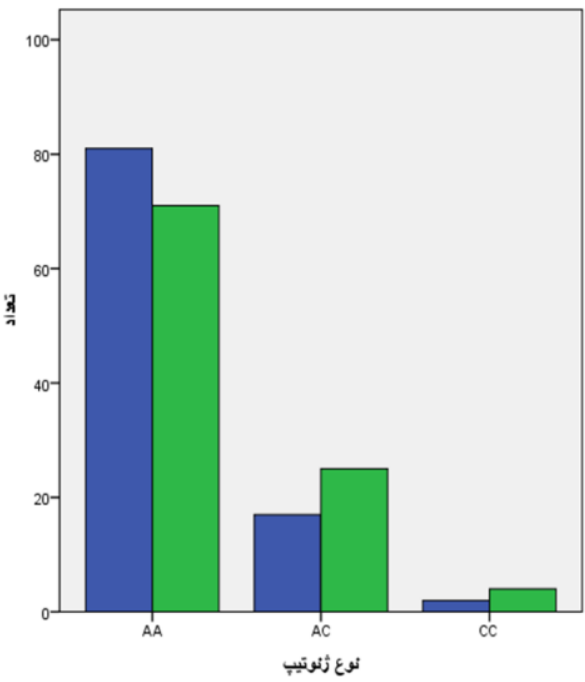

دبsion

شكل شماره ه. نمودار ميله اى براى بررسى هم زمان نحوه توزيع رنوتيب هاى افراد سالم و بيمارن ديابتى در جامعه مورد بررسى

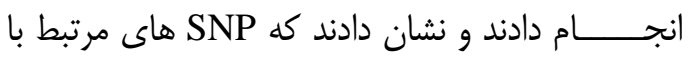

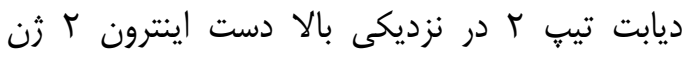
CASQ1

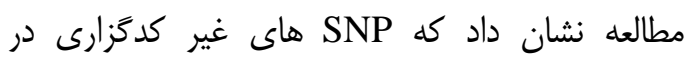

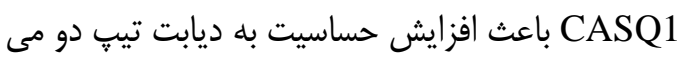

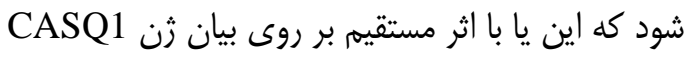

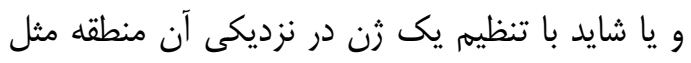

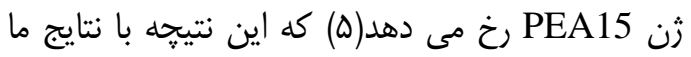

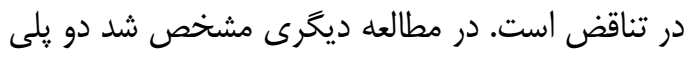

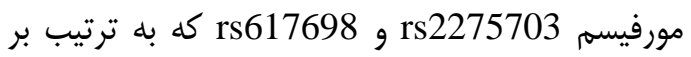

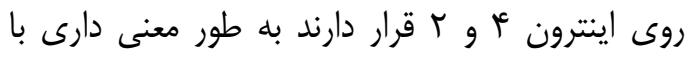
ديابت تيب r مرتبط هستند. اين نتايج نشان داد كه آلل

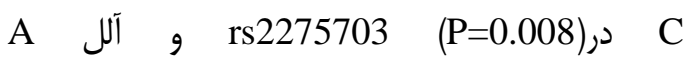
درrs617698(P=0.04 با افزايش خطر ابتلا به ديابت تيٍ ץ در ارتباط است(9). باز در دو بررسى ديخر بر روى ارتباط جهش ثن Calsequestrin1 با بيمارى عضلات اسكلتى در طى تغيير انتشار كلسيه ساركويلاسمى

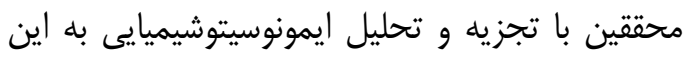

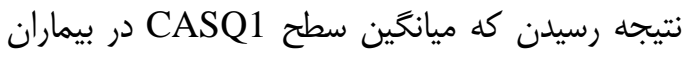

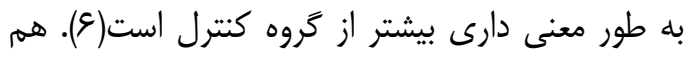

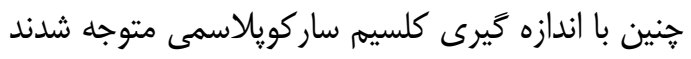

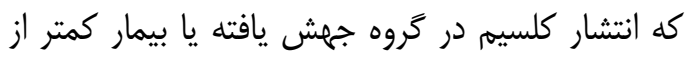

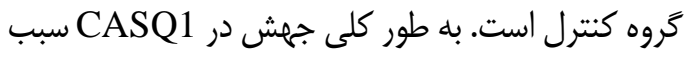

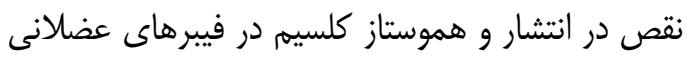
مى شود كه سبب كرفتخى و ضعف و خستخى عضلات

\section{بحث و نتيجه كَيرى}

با توجه به نقش عوامل زنتيك ديرى در بيمارى ديابت و

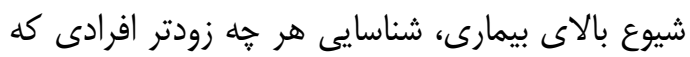

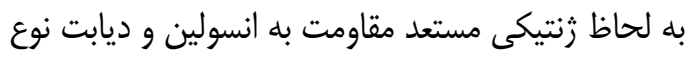

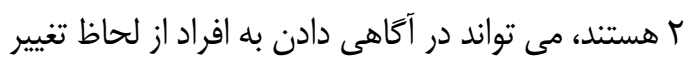
نوع زندگى، رزيم غذايى، و بررسى دقيق سلامت جامعان

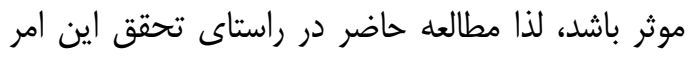

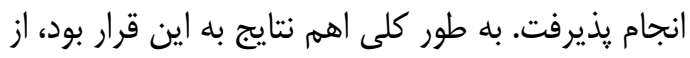

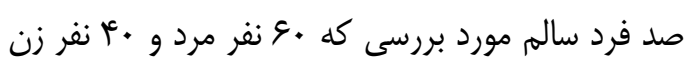

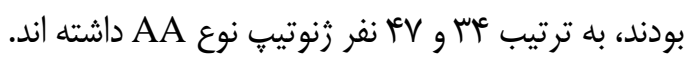

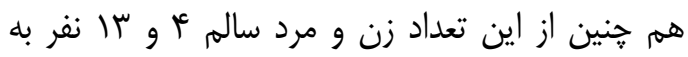

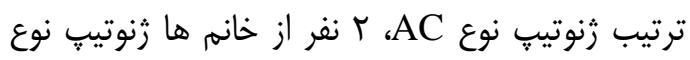

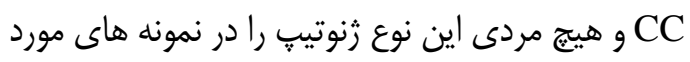
بررسى نداشتند. هم جنين از صد فرد سالم و صد صد نفر

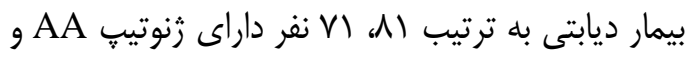

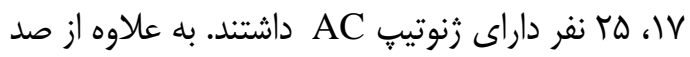

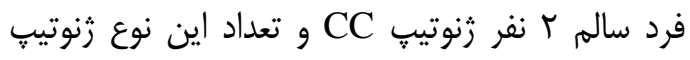

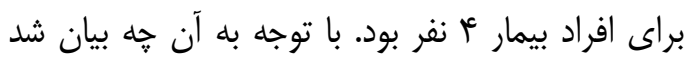

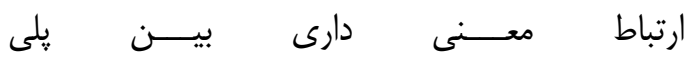

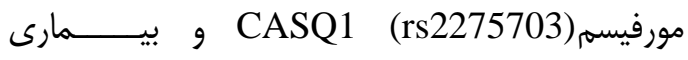

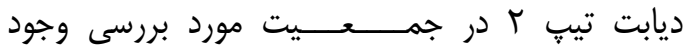
نداشت(P=0.241). در ارتباط با تاريخجه كار بايد كَفت در طى يزوهشى

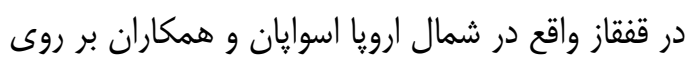

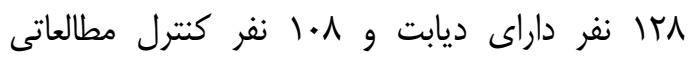




$$
\begin{aligned}
& \text { مقاله حاضر بـــشى بركـــفته از يك طرح }
\end{aligned}
$$

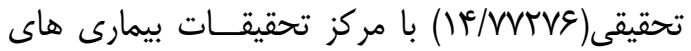

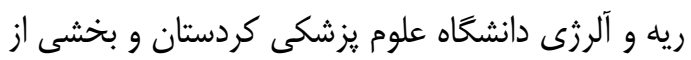

$$
\begin{aligned}
& \text { پايان نامه كارشناسى ارشد خانم سميه بداقى دانشجوى دان } \\
& \text { كارشناسى ارشد علوم سلولى و مولكولى دانشخاه آزاد }
\end{aligned}
$$

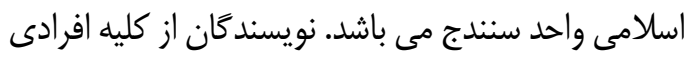

$$
\begin{aligned}
& \text { كه در اين بررسى شركت داشتند، قدردانى مى نمايند. }
\end{aligned}
$$

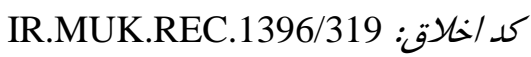

\section{References}

1.Mack LR, Tomich PG. Gestational diabetes diagnosis classification and clinical care. Obste Gynecol Clin North Am2017; 44:207-17. doi: 10.1016/j.ogc.2017.02.002. 2.Galleri L, Sebastiani G, Vendrame F, Grieco FA. Viral infections and diabetes. Adv Exp Med Biol 2012; 771: 252-71. doi: 10.1155/2014/804519.

3.Davidson MB. Correction to the 2010 report on the diagnosis and classification of diabetes. Diabetes Care 2010; 33: 57. doi: 10.2337/dc09-2368.

4.Nolan CJ, Damm P, Prentki M. Type 2 diabetes across generations from pathophysiology to prevention and management. Lancet 2011; 378: 169-81. doi: 10.1016/S0140-6736(11)60614-4

5.Rossi D, Vezzani B, Galli L, Paolini C, Toniolo L, Pierantozzi E, et al. A mutation in the CASQ1 gene causes a vacuolar myopathy with accumulation of sarcoplasmic reticulum protein aggregates. Hum Mu 2014; 35:1163-70. doi: 10.1002/humu.22631.

6.Adamo MC, Sforna L, Visentin S, Grottesi A, Servettini 1, Guglielmi L, et al. A calsequestrin1 mutation associated with a skeletal muscle disease alters sarcoplasmic $\mathrm{Ca}_{2}+$ release. Plos One 2016; 11:155516. doi.org/10.1371/journal.pone.0155516.

7.Cheung CY, Tso AW, Cheung BM, Xu A, Ong KL, Law LS, et al. Genetic variants

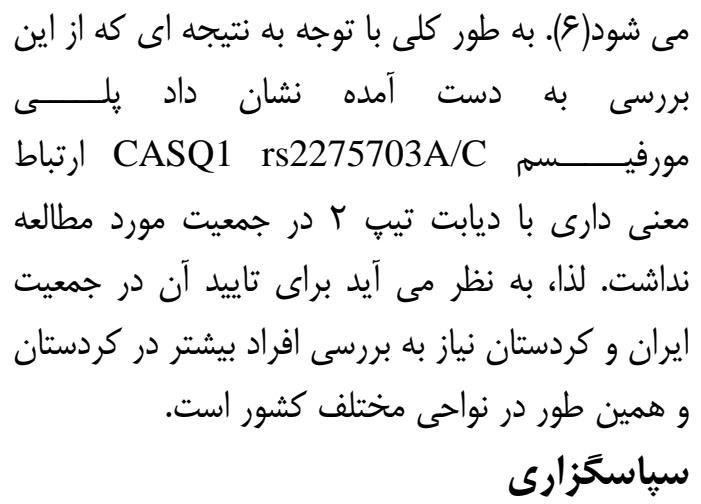

associated with persistent cen tral obesity and the metabolic syndrome in a 12 year lon -gitudinal study. Eur J Endocrinol 2011; 164: 381-8. doi: 10.1530/EJE-10-0902

8.Swapan D, Winston C, Zhengxian Z, Sandra J. CASQ1 gene polymorphisms under chromosome 1q21 linkage peak are associated with type 2 diabetes in Northern European Caucasians. Diabetes 2004; 53:3300-6.

doi.org/10.2337/diabetes.53.12.3300.

9.Fu M, Damcott CM, Sabra M, Pollin TI, et al. Polymorphism in the Calcequestrin 1 gene on chromosome 1q21 is associated with type 2 diabetes in the old order Amish. Diabetes 2004; 53: 3292-3299. doi: 10.2337/diabetes.53.12.3292.

10.Fu M, Gong DW, Damcott C, Sabra M, Yang R, Pollin TI, et al. Systemic analysis of omentin 1 and omentin 2 on 1q23 as candidate genes for type 2 diabetes in the old order Amish. Diabetes 2004;53:59-63.

11.Wright JR, Yang $\mathrm{H}$, Hyrtsenko $\mathrm{O}, \mathrm{Xu}$ BY, Yu W, Pohajdak B. A review of piscine islet xenotransplantation using wild type tilapia donors and the production of transgenic tilapia expressing a humanized tilapia insulin. Xenotransplantation 2014;21: 485-95. doi: 10.1111/xen.12115 
The Prevalence of Different Genotypes CASQ1 rs2275703 (A / C) in Patients with Type 2 Diabetes Mellitus

\author{
Nasirikalmarzi $R^{l}$, Bodaghi $S^{2}$, Fatahirad $A^{3}$, Keshavarzi $F^{2 *}$
}

(Received: June 1, 2019

\begin{abstract}
Introduction: Genetic factors play an important role in the development of type 2 diabetes. The aim of this study was to investigate the prevalence of polymorphism CASQ1 (rs2275703) in 100 patients with type 2 diabetes mellitus (T2DM) in Kurdistan, Iran.

Materials \& Methods: This study was conducted based on a case-control design. After obtaining the informed consent, the blood samples were obtained from patients with T2DM who were over 35 years of age. In total, 100 blood samples from the patient group and 100 blood samples from the control group (with matched age and gender) were assessed for the status of CASQ1 (rs2275703) using Tetra-Arms polymerase chain reaction method. The data were then analyzed statistically. Ethics code: IR.MUK.REC.1396/319
\end{abstract}

Findings: Out of 100 healthy individuals (60
Accepted: November 24, 2019)

males and 40 females), 34 and 47 ones had genotype AA4, respectively. Moreover, 4 and 13 cases had genotype $\mathrm{AC}$, and 0 and 2 individuals had genotype CC. Additionally, out of all healthy individuals and diabetic patients, 81 and 71 cases had genotype AA, respectively; moreover, 17 and 25 cases had genotype AC. In addition, out of 100 healthy individuals and 100 patients, 2 and 4 cases had genotype CC, respectively. There was no significant relationship between CASQ1 rs2275703 polymorphism and T2DM $(\mathrm{P}=0.241)$.

Discussion \& Conclusions: According to the results, no significant relationship was observed between CASQ1 (rs2275703) polymorphism and T2DM in the population under study.

Keywords: Polymorphism, CASQ1 rs2275703, Type 2 diabetes mellitus

1. Lung Diseases and Allergy Research Center, Kurdistan University of Medical Sciences, Sanandaj, Iran

2. Dept of Biology, Islamic Azad University, Sanandaj Branch, Sanandaj, Iran

3. Tohid Hospital, Kurdistan University of Medical Sciences, Sanandaj, Iran

*Corresponding author Email: fkeshavarzi@iausdj.ac.ir

\title{
Scientific Journal of Ilam University of Medical Sciences
}

